\title{
COPPER AND CADMIUM LEVELS IN HAIRS \& NAILS;
}

\author{
An indicator of heavy metal pollution.
}

\section{Miss Asma Ayyub, Dr. Muhammad Shakeel Ahmad, Prof. Dr. Naheed Ikram, Um-e-Ammara Shan}

SUMMARY... Heavy metals ingested or inhaled can affect liver, Brain, Bone and lungs. Raised copper and cadmium levels have been seen in ischemic heart disease. A level of trace elements varies in blood among population. In this study Copper \& Cadmium levels were determined in hairs and nails; easy to sample and store. Purpose of this study is to find out relationships with heavy metals pollution and try to develop as a screening test. Such work is not yet done in our population. 86 male subjects and 20 controls (male) were selected for determination of $\mathrm{Cu} \& \mathrm{Cad}$ concentrations in hairs and nails. Medical history was noted. 3-4 fingernails and 1 tbsp of hair cut from the nape of neck close to root were obtained. Samples were analyzed by atomic absorption spectrophotometer. Highly significant $(p<0.001)$ raised copper levels were seen in hairs and nails of subjects $(110.79+26.01 \& 99.34 \pm 7.81 \mu \mathrm{g} / \mathrm{gm}$ respectively) compared with control $(80.76 \pm 7.81 \& 77.65 \pm 2.48)$. Similarly significantly $(p<0.001)$ raised Cadmium levels were found in subjects (hairs $143.57 \pm 62.03 \&$ nails $104.71 \pm 74.52)$ compared with control $(89.20 \pm 12.98 \& 77.54 \pm 12.32)$. Highly significant $(p<0.001)$ raised values of Cd \& Cu indicate that hairs and nails concentration may indicate heavy metals pollution \& it can be easy sampling test for screening of pollution about heavy metal exposure.

Key words: Cu \& Cd, hair, nail, heavy metal pollution, screening test.

Article Citation

Ayyub A, Ahmad MS, Ikram N, Shan U. Copper and cadmium levels in hairs \& nails; An indicator of heavy metal pollution. Professional Med J 2013;20(2): 296-300.

\section{INTRODUCTION}

Trace elements play an important role in human health and disease. These elements participate in tissue, cellular and sub-cellular functions, including immune regulation, nerve conduction, muscle contraction, membrane potential, mitochondrial activity etc. The concentration at which metals may be considered important vary as some are essential at low level yet toxic at other ${ }^{1}$. When metals are ingested or inhaled in excessive amount, heavy metals can affect liver, brain, bone and lungs although each metal also causes its own characteristic symptoms ${ }^{2}$. Prolong exposure to low doses can cause chronic lung disease, cancer, nervous impairment, bone abnormalities, sterility ${ }^{3}$.

Copper is an essential substance to human life, however its critical dose can cause anemia, adrenal hyperactivity and insufficiency, allergies, hair loss, arthritis, depression, elevated cholesterol, tooth decay, vitamin $\mathrm{C}$ and other vitamin deficiencies ${ }^{4,5}$.

Elemental copper may be a source of toxicity when leached from copper piping into water supplies or inhaled occupationally as dust or fumes ${ }^{6}$.Short term copper exposure can cause gastrointestinal distress while long term exposure can damage liver or kidney?. Cadmium is a cumulative toxic agent having half life in blood 2-3 months ${ }^{8}$. Cadmium also causes a rise of copper kidney concentration; the content of latter in liver as well as activity of some copper dependant coenzymes undergoes transient changes. The effect of cadmium greatly depends on its dose and exposure time as well as dietary content of iron, zinc and copper ${ }^{9}$. Nagra et al; study data shows higher serum cadmium concentration associated with ischemic heart disease and hypertension ${ }^{10}$ and treatment with cadmium $(0.4 \mathrm{mg} / \mathrm{kg}$ wt.) significantly increased lipid per oxidation in heart within 3 hours of cadmium injection ${ }^{11}$. Raised serum copper remains high in all ischemic heart disease patients ${ }^{12}$.

Above mentioned data clearly indicate dangerous status of heavy metals to health. So, toxic status should be evaluated to protect human health. Since 
last decade there are number of studies investigated metals level in body fluid of trace elements in blood varies considerably among global population and normal range for typical population were different ${ }^{13}$. Blood minerals levels are kept within a very tight range. An alternative is to measure minerals directly in the body tissue or cell, a body tissue that is painless to sample and easy to store \& transport are hairs and nails $s^{14,15,16}$.

Purpose of study is to find out base line information about levels of copper and cadmium in hairs and nails in our population as previously such work has not been done. Significant result may lead to develop a better and easy diagnostic measure about metal toxicity particularly as screening program.

\section{METHODS AND MATERIALS}

Eighty six subjects and 20 controls were selected for study. Subjects were from different occupations and area of living i.e. jewelers, automobile workshops, and person living in agricultural field, pica factory workers and ternaries.

Control subjects were approximately healthy and nonsmokers. History about smoking, occupation and diet were noted and examined by a medical officer for any sign and symptoms. Hairs and nails texture, age and blood pressure were also noted. Hairs and nails were the study sample to determine the copper and cadmium concentration. With nail clipper 3-4 fingers nails were taken. One tablespoon of hair of each person was cut from nape of neck close to the root using a stainless steel scissors, every nail and hairs sample was kept in a plastic bag. These samples were weighed by analytic balance and transferred to a beaker adding $5 \mathrm{ml}$ nitric acid. After 5 minutes $2 \mathrm{ml} \mathrm{H}_{2} \mathrm{O}_{2}$ was added then transferred to the condenser flask and reflux it for $1 / 2$ hour. After cooling the samples to room temperature volume was making up to $25 \mathrm{ml}$ with deionized water. Then samples were analyzed on atomic absorption spectrophotometer A1800 Hitachi
Japan. The instrument was calibrated periodically using copper and cadmium standard solutions. Each solution was measured twice. Mean concentrations were computed using an IBM compatible computer.

\section{RESULTS}

In this survey 86 subjects having mean age $32.65+9.59$ year and 20 controls were sampled for copper and cadmium level in hair and nails 56 subjects were smoker with mean smoking period 8.5 years. In control group (20) copper cone in hair and nail sample were $80.76 \pm 7.81$ and $77.65 \pm 2.48$ respectively, while cadmium levels were $89.20 \pm 12.98$ and $7.54 \pm 12.32$ respectively. Copper levels in hairs and nails of 86 subjects were significantly raised $10.79 \pm$ $26.01 \mu \mathrm{g} / \mathrm{g} \quad \mathrm{p}<0.001$ and $99.34 \pm 28.27 \mu \mathrm{g} / \mathrm{gm}$ $p<0.001$ respectively when compared with control.

Similarly cadmium level I hairs and nails were highly significant $p<0.001 \quad 143.57 \pm 62.03$ and $104.71 \pm 74.50$ respectively compared with control (table-I) out of 86 subjects nail cadmium level in 21 subject were $>200 \mu \mathrm{g} / \mathrm{gm}, 19$ have cad level b/w 100 $200 \mu \mathrm{g} / \mathrm{gm}$ while 46 have $84-99 \mu \mathrm{g} / \mathrm{gm}$ cadmium level. On the other hand 22 out of 86 subjects nail cadmium level in hair $>200 \mu \mathrm{g} / \mathrm{gm} 25$ have 100-200 $\mu \mathrm{g} / \mathrm{gm}$ while in 39 subjects cadmium level were in the range of 77.6-99 $\mu \mathrm{g} / \mathrm{gm}$. Pattern of copper level in the hairs and nails was not similar to the cadmium level. Only 18 out of 86 copper level $>100 \mu \mathrm{g} / \mathrm{gm}$ in hair and 10 out of 86 have nail cu level of $>100 \mu \mathrm{g} / \mathrm{gm}$. Table-II shows various sing and symptoms noted in subjects only 17 out of 86 were symptoms and sign free. Blood pressure noted was $118.67 \pm 1.45 / 82.97 \pm 7$. TableIII shows number of subjects belongs to different area or occupation.

\section{DISCUSSION}

Metals are toxic these bind with ligand of biological structure $^{17}$. One of the major ever-increasing problems is the influence of pollution especially heavy metals contaminants. When such toxic metals accumulate \& 


\begin{tabular}{|l|c|c|}
\hline \multicolumn{1}{|c|}{ Parameter } & $\begin{array}{c}\text { Control (20) } \\
\text { male }[\boldsymbol{\mu g} / \mathbf{g m}]\end{array}$ & $\begin{array}{c}\text { Subjects (86) } \\
\text { male }[\boldsymbol{\mu g} / \mathbf{g m}]\end{array}$ \\
\hline Hair copper & $80.76 \pm 7.81$ & $110.79 \pm 26.01^{*}$ \\
\hline Nail copper & $77.65 \pm 2.48$ & $99.34 \pm 28.27^{\star}$ \\
\hline Hair cadmium & $89.20 \pm 12.98$ & $143.57 \pm 62.03^{*}$ \\
\hline Nail cadmium & $77.54 \pm 12.32$ & $104.71 \pm 74.52^{*}$ \\
\hline Age & $27 \pm 8.10$ & $32.65 \pm 9.59 *$ \\
\hline
\end{tabular}

Table-I. Copper \& cadmium level in hair and nails ${ }^{\star} P<0.001$

\begin{tabular}{|c|c|}
\hline Symptoms & No. of subjects $(\mathbf{n}=\mathbf{8 6})$ \\
\hline Skin irritation & 2 \\
\hline Joint / bone pain & 4 \\
\hline Headache & 16 \\
\hline Anemia & 17 \\
\hline GIT disturbance & 9 \\
\hline Muscle cramp & 9 \\
\hline Chest distress & 4 \\
\hline Weakness & 17 \\
\hline Table-II. Sign /Symptoms noted during sampling \\
\hline
\end{tabular}

\begin{tabular}{|l|c|}
\hline Jewelry workshop workers & 22 \\
\hline Automobile workshop workers & 21 \\
\hline Rice factory workers & 10 \\
\hline Agriculture area & 18 \\
\hline Lather tanneries & 5 \\
\hline General population & 10 \\
\hline
\end{tabular}

Table-III. Distribution of Subjects ( $\mathrm{n}=86$ Male)

become threat to the human health then determination of their levels become important in term of easy \& effective diagnosis. Hairs and nails act as an indicator of body stores of heavy metals ${ }^{18}$.

Table-I clearly shows that copper conc. in hairs \& nails were significant $(p<0.001)$ raised level $(110.79 \pm 26.01 \& 99.33 \pm 28.27$ respectively) found in subjects when compared with control group. Benson ${ }^{19}$ also found significant difference $(\mathrm{P}<0.01)$ of copper in hairs, in school children when compare with standards. Result of cadmium conc. were similarly highly significant $(p<0.001)$. However subjects have wide standard deviation of hairs and nails $\mathrm{Cd}$ conc. $(143.57 \pm 62.03 \& 104.71 \pm 74.52)$. Reason of wide standard deviation is presence of group with very high Cd conc. e.g. 21 out of 86 have $\mathrm{Cd}$ conc. $>200 \mu \mathrm{g} / \mathrm{gm}$, 19 have Cd conc. between 100-200 $\mu \mathrm{g} / \mathrm{gm}$ and 46 show conc. $84-99 \mu \mathrm{g} / \mathrm{gm}$. Such group fluctuation was not seen in copper cone. In 86 male subjects.

One obvious reason for raised cadmium level in subjects may be due to presence of 56 smokers out of 86 subjects. In a study no significant effect on $\mathrm{Cd}$ conc. could be detected in children exposed to environmental tobacco smoking ${ }^{20}$. Cause of raised copper and cadmium levels in hairs may be environmental pollution. Metal cleaning operation, leather tanneries, copper pipe, electronic instrument, jewelry and copper welding are source of copper and cadmium pollution. Considerable level of copper maybe present in municipal sewage bulk of this originates from industrial discharge ${ }^{21}$. Excessive $\mathrm{Cd}$ exposure has been occurred in general population through ingestion of contaminated food and water ${ }^{22}$.

Our study data shows that in jewelry worker hairs and nails Cu conc. (91.75 $\pm 15.2 \& 84.72 \pm 9.52)$ and automobile worker (112.47 $\pm 58.56 \quad \& 89.9 \pm 37.7$ $\mu \mathrm{g} / \mathrm{gm}$ respectively) were raised compared with $\mathrm{Cu}$ level in hair and nail of subject living in agricultural area (84.9 $\pm 8.57 \& 81.09 \pm 7.57 \mu \mathrm{g} / \mathrm{gm}$ respectively). Highly raised level of $\mathrm{Cd}$ found in rice factory workers nails and hairs $(249.27 \pm 7.81 \& 244.1 \pm 8.05 \mu \mathrm{g} / \mathrm{gm}$ respectively.) than any other group. When we compare our control subjects $\mathrm{Cu}$ and $\mathrm{Cd}$ concentration in hair and nail with WHO criteria (hair/ nail copper $20 \mu \mathrm{g} / \mathrm{gm}$ and cadmium hair/nail $0.2 \mu \mathrm{g} / \mathrm{gm}$ ) raised level of $\mathrm{Cu}$ and $\mathrm{Cd}$ were found in hairs and nails of control. This shows that our control have been exposed to 
generalized $\mathrm{Cu}$ and $\mathrm{Cd}$ pollution. Overall our occupational group clearly shows highly significant raised values, which indicate burden of occupational pollution.

Table-II shows that different numbers of subjects have some sign and symptoms only 17 subjects were sign/symptom free. Many studies data have shown the effects of copper and cadmium accumulation on body health more or less similar sings/symptoms mentioned in this study $23,24,25$ and 26 .

Our study data show highly significant $(P<0.001)$ raised level of copper and cadmium in hairs and nails compared with control. It also indicates of generalized and occupational $\mathrm{Cu}$ and $\mathrm{Cd}$ pollution. History of subject also indicates sing/ symptoms may be related to $\mathrm{Cu}$ and $\mathrm{Cd}$. Toxicity which may be further evaluated finally hair and nail sampling prove not only easy but also extant good diagnostic and may be used for $\mathrm{Cu}$ and $\mathrm{Cd}$ toxicity screening program.

Copyright(C) 01 Jan, 2013.

\section{REFERECES}

1. Majid Mumtaz, Azhar Siddique, Nadia Mukhtar and Tabassum Mehboob. Status of trace elements level in blood samples of different age population of Karachi (Pakistan) Tr. J of Medical Science 1999; 29: 697-699.

2. Macfarland and H.N, Pulmonary effects of cadmium in Mcnnear. J.E (Ed) Cadmium Toxicity Dekker New York PP 113-132.1986.

3. M. Ali Khan and Saad Aki Khan. Environmental pollution; A Menace to Public health: Sci. int (Lahore) 1989; 1(6): 400-408.

4. F.I. Abdulrehman , J. C. Akan , Z. M. chellube and M Waziri. Levels of Heavy metals in human hair and nail samples from Maiduguri Metropolis, Borno state Nigeria. Dol:10.5923/J.env.2012;2(4):81-89.

5. McLean CM , Koller CE, Rodger JC and GR MacFarlane. Mammalian hair as an accumulative bioindicator of metal bioavailability in Australial terrestrial environments. Sci total Environ. $2009 ; 15: 407(11)$ : 3588-96.
6. Lichiang, Bruce D, James and Robert J Magee. A review of electro-analytic determination of some important elements ( $\mathrm{Zn}, \mathrm{Cd}, \mathrm{Cu}, \mathrm{As})$ in environmental samples. Sci. Int (Lahore)1992; 4(1); 25-37.

7. Mukesh Mathrani and Zeenat Khwaj. Content of metals in drinking water of Hyderabad. Pak. J. chem . 2001; 29;34-38.

8. William WT. Plumbum. Karachi quovadis J. Pak. Med. Ass. 1988; 3; 227-228.

9. Zakladu, Polstaw Zywienia, Czlowieka et al. Harmful elements and iron zinc and copper interactions in the animals and human being Rocz panstw Zaki Hig 1991; 42(3); 269-276.

10 Mi-sun lee, sung kyun Park ,Howard Hu and Sundong Lee. Cadmium exposure and cardiovascular disease in the $\mathbf{2 0 0 5}$ Korea national health and Nutritional examination survey. Environmental Research 2011;111(1):171-176.

11. Nagra S.A, Zikriya B abd Maqbool T. Determination of serum cadmium and level in patients of ischemic heart disease associated with or without hypertension and diabetes mellitus. Pakistan J. Med. Res. 1998; 37 (4); 170-172.

12. Shah Nawaz Khan, M. Ataur Rehman and Smad. Trace elements in serum from Pakistani patients with acute and chronic ischemic heart disease and hypertension. Clin. Chem. 1984; 30 (5): 644-648.

13. Baxadear Sc and Farre-Ravia. Whole blood and serum copper level in relation to sex and age, Rev. Espde Fisiol 1986; 42; 213-217.

14. Khuder A, bakir MA Hasan $\mathrm{R}$ and $\mathrm{A}$ Muhammad. Determination of Nikel, Copper, Zink and lead in human scalp hair in Syrian occupationexposed workerby total reflection X-ray fluorescence. Environ Mont Assess. 2008: 143(1-3);67-74.

15. AR Hashim and KF Abed. Aluminium, Cadmium, and microorganism in female hair and nails from Riyadh. Saudi Arabia J medical sciences 2007: 7 (2);263-266.

16. Olwin. Us environmental protection agency (EPA- 6-479-049). Toxic trace metals in mammalian hair and 
nail. August 1979.

17. M.N. chattergea, Rana Shinda. Metabolim of minerals and trace elements. Text book of medical biochemistry 2004. $6^{\text {th }}$ edition. pp 547-554.

18. Vishwanathan H, Hema A, Edwin D, MV Rani. Trace metal concentration in scalp hair of occupationally exposed autodrivers. Environ Monit Assess 2002; 77(2):149-154.

19. Benson Ogboko, Copper and zinc concentration in Hair of Healthy children in ceres district of South Africa. J. Basic. Appl. Sci. Res, 2011;1(8) :818-824.

20. Sanaulllah P. Tobacco and cancer study. J. Sc. And Tech. University. Peshsawar 2000; 24 (1-2); 53-57.

21. Timm reck T. C and G. Shook. Environmental health and occupational health implication of baritosis; a pneumoconiosis J. environ. Health 1992; 55; 22-26.
2. Kjellstrain T, Shiroishi K, Evrin P. Urinary z-microglobin excretion among people exposed to cadmium in the general environment. And epidemiological study in cooperation between Japan And Sweden. Environ Res $1977 ; 13 ; 318-344$.

23. Hasan N, Emery D, Baithun SI and Dodds. Chronic copper intoxication due to ingestion of coins, a report of unusual case. Hum. Exp. Toxicol 1995; 14; 500 502.

24. Weatherall DJ. Lodingham JGG warrel DA. Oxford Text Book Of Medicine ${ }^{\text {rd }}$ Ed. New York; Oxford University press inc. 1996.

25. Bouley G. Dubrevil A, Despause N \& Boudene C. Toxic effect of Cadmium micro-particles on respiratory system. Scand. J. work. Environ. Hea;th 1997; 3; 116; 121.

26. Bernard A and Lauwerys R. Cadmium in human population experiential. 1986; 50; supplement 114123.

\section{AUTHOR(S):}

1. MISS ASMA AYYUB

MSc (Biochemistry)

Department of Chemistry,

B.Z.U. Multan, Pakistan.

2. DR. MUHAMMAD. SHAKEEL AHMAD

Assistant professor Biochemistry

Nishter Medical College Multan, Pakistan.

3. PROF. DR. NAHEED IKRAM

Department of Chemistry,

B.Z.U. Multan. Pakistan.
4. Miss Um-e-Ammara Shan

Department of Chemistry,

B.Z.U. Multan. Pakistan.

Correspondence Address:

Dr. Muhammad Shakeel Ahmad

Assistant professor Biochemistry

Nishter Medical College Multan, Pakistan.

runthabery@hotmail.com

Article received on: 12/03/2007 Accepted for Publication: $\quad$ 01/01/2013 Received after proof reading: 07/02/2013

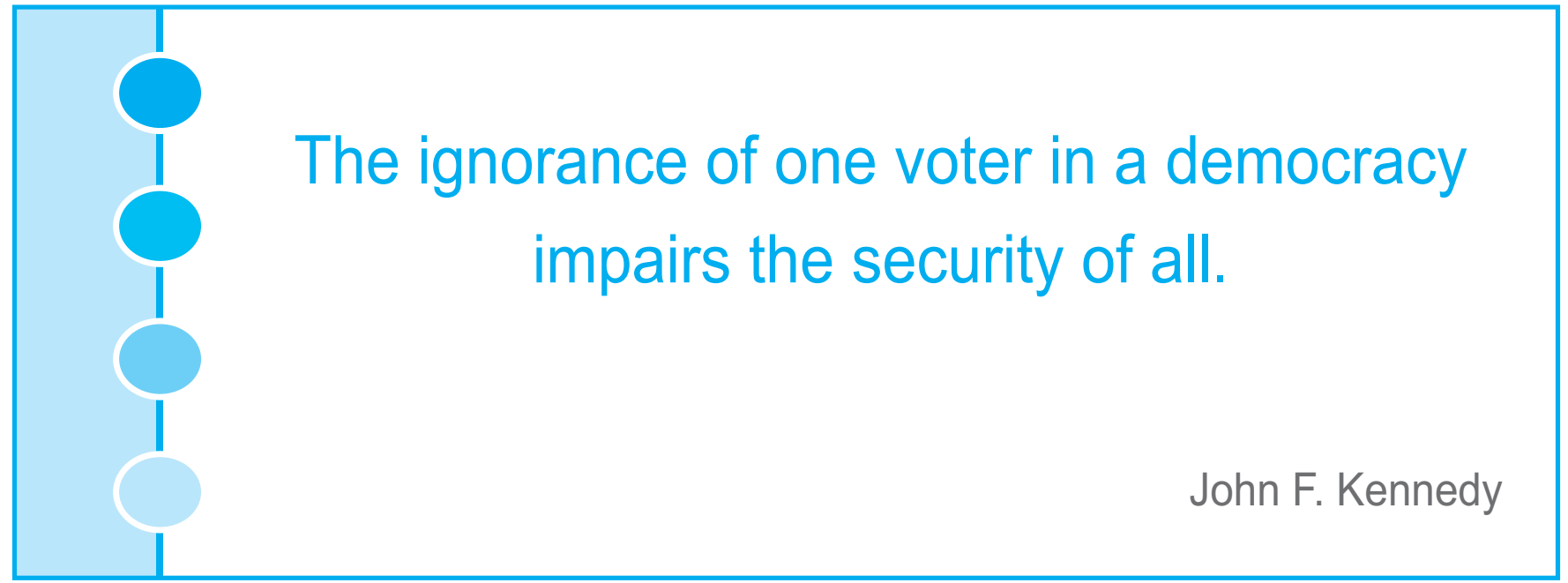

